ISSN No:-2456-2165

\title{
Gender Disparities in Tanzania: Legal Framework Vis-a Vis Practice
}

\author{
Sr.Ester JohnKilatu* and Daniel Kulwa*
}

\begin{abstract}
Gender disparities exist since antiquity. There has been inequality based solely on gender in various aspects of life usually in favour of men. Such inequalities are evident in employment, earning, education, leadership, land ownership, language use, religion, health rights and decision making. Tanzania like any other countries has incorporated gender in various legal instruments, policies, institutions and various strategies that have been employed to replicate gender gap in the country.
\end{abstract}

It has been noted that life has been stratified by system of oppression and privileges. Throughout history women have been confined to uninvisible, unpaid and undervalued work. ${ }^{1}$ Accordingly, we cannot eliminate gender disparities unless the community is convinced and ready to embrace new practices. Furthermore, it has been observed that Tanzania has undergone major legal reforms to mitigate gender disparities. The Land legal regime provide for women safeguard, though such right cannot be realized as patriarchal practices places women to a disadvantaged position, besides, inheritance and marriage laws are still weak and discriminate against women thus, diversely affect their land rights. It is recommended that 'will' writing practices and willingness of the court to honor and enforce the law may mitigate the problem since reform on inheritance law has been proved ineffective.

Therefore, this article discusses the patterns of disparities in the legal framework concerning women vis-a vis its practices blatantly inconsistent with the principles of equality and non-discrimination and the spirit of the constitution and international conventions which Tanzania signed without reservation.

* LL.B (SAUT), PGDLP (LST), LL.M in Corporate and Commercial Law(UDSM), Assistant Lecturer and Corporate Secretary of SAUT- Arusha Centre, Serving as Coordinator for Mobile Legal and Counseling Clinic of the Little Sisters of St. Francis.

*Daniel Kulwa BAED (SAUT), MA- in History (SAUT) Assistant Lecturer and Examination officer SAUT- Arusha Centre

${ }^{1}$ G.W. Peterson and K.R. Bush (eds.), (2013) Handbook of Marriage and the Family, DOI 10.1007/978-1-4614-39875_7, (C) Springer Science+Business Media New York, p.149.

\section{INTRODUCTION}

Gender disparities place women to unprivileged position in every aspect of life. There is numerous evidence of discrimination against women in Medieval Europe where women were denied right to property ownership, the right reserved for men, women had no right to neither study nor participate in public life like voting or being voted. ${ }^{2}$ By late $20^{\text {th }}$ century, some few states in the United States had begun granting suffrage to women. Where else some countries Africa, including Tanzania has put in place various policies and laws to enforce extra guarantee on women rights at global, regional and domestic level; though some societies continue to suppress and ignore them.

\section{A. Historical Background of the Study of Gender Disparities}

Gender is regarded as an important aspect in people's lives. The origin and causes of gender disparity is still debatable among the scholars. Social attitudes toward women vary significantly across societies ${ }^{3}$ Gender differences on the other hand, arise from the socially constructed relationship between men and women ${ }^{4}$. Additionally, it appears that some gender inequality arose in all human societies as a result of the division of labour suggested by women's childbearing responsibilities.Women's universal responsibility for childbearing appears to have created such a differentiation between the sexes that it always resulted in a gender division of labour in all simple societies. ${ }^{5}$

It is argued that labour division between men and women within the societies brought the concept of gender disparity. It happed when women and men received distinctive responsibilities and because those responsibilities placed them more often in the company of their own gender, gender became a primary division in

\footnotetext{
${ }^{2}$ The same fact exists in other countries as in parts of Germany women were subject to be sold by their husband, where else in France women were compelled to cover their heads in public. Also available at: https://www.britannica.com/topic/feminism Accessed on 09th July, 2020 at 14:42 hrs.

${ }^{3}$ Giuliano P. (2017) Gender: An Historical Perspective Bonn, IZA - Institute of Labor Economics

${ }^{4}$ Oakley, A. (1972) Sex, Gender, and Society. London: Temple Smith.

${ }^{5}$ Jackson M. R., (1998), Destined for Equality, New York. Cambridge University Press
} 
culture and women and men developed opposing gender identities ${ }^{6}$ Similarly, the responsibility given in the societies produced verities of duties, where women became child rearing and men involved in hunting, fishing, and war, tasks that required readiness for more distant travel and danger. ${ }^{7}$

Furthermore, Men's activities in this division of labour were more likely to award them superior political organization and a relative monopoly over women. The tasks that men always involved commonly demanded coordination and organization, therefore, resulted particularly in response to reproductive differences, pushed men into positions of leadership, though with a limited amount of power, while simultaneously giving them superior resources. ${ }^{8}$

However, these differences affect the distribution of resources and responsibilities between men and women, and are shaped by ideological, religious, ethnic, economic, and cultural determinants. ${ }^{9}$ All this actually became important and effective when societies started to become stratified by classes, organized around unequal control over finite, contested productive resources particularly land. ${ }^{10}$

\section{CONCEPTUAL AND THEORETICAL FRAMEWORK}

\section{Definitions of Concepts}

\section{- Gender}

The meaning of this concept has been changing from time to time. For example FAO defined gender as 'the relations between men and women, both perceptual and material. Gender is not determined biologically, as a result of sexual characteristics of either women or men, but is constructed socially. It is a central organizing principle of societies, and often governs the processes of production and reproduction, consumption and distribution ${ }^{11}$.

Moreover, Gender refers to attitude, feeling and behavior that a given culture associates with a person's biological sex. ${ }^{12}$ Where else, 'sex' refers to one's biological status as female or male or intersex. Sex may be identifiable through various indicators which include sex

\footnotetext{
${ }^{6}$ Ibid.

${ }^{7}$ Ibid.

${ }^{8}$ Ibid.

${ }^{9}$ Moser, C. 1989. Gender planning in the Third World: Meeting practical and strategic gender needs. World Development, Vol. 17 (11): 1799-1825.

${ }^{10}$ Jackson M. R., (1998), Destined for Equality, New York. Cambridge University Press

${ }^{11}$ FAO. (1997) Gender: the key to sustainability and food security. SD Dimensions, May 1997 (http://www.fao.org/sd).

${ }^{12}$ Ibid
}

chromosomes, gonads, internal reproductive organs and external genitalia. ${ }^{13}$

Accordingly, Gender identity refers to an inward sense of being male, female, both, neither, or any other gender(s). The identity is not visible as so it is how we see ourselves but an outward expression of one's gender is what we call gender expression. Such expression includes mannerism, clothing, hair and other mode of expression which are not necessarily indicators of a person's identity. Behaviors which are compatible to one's culture refers to gender-normative which those inconsistent to the societies expectations are vied as gender non-conformity. When a person acts or communicates gender in a given society that is known as gender expression. Thus, it may appear that some people may act or conduct a lifestyle inconsistent to one's gender identity and role prescribed in a given culture. $^{14}$

\section{- Gender Disparities}

According to European Institute for Gender Equality (EIGE) means differences in women's and men's access to resources, status and well-being, which usually favour men and are often institutionalized through law, justice and social norms. ${ }^{15}$ On the other hand, gender disparity is the systematic, unfavourable treatment of individuals on the basis of their gender, which denies them rights, opportunities or resources. Since antiquity women have been restricted to public life participation in favour of men as childcare remains women's providence since women are better suited for house work and men are better suited for providing through paid work. ${ }^{16}$ There is no justifiable reason on gender disparities and it remains unclear whether biological factors such as endocrinology and genetic contribute to variation in treatment based on gender. However it is evident that women have been traditionally undermined and excluded from public life only because they are born women. Community sensitization on equality and willingness to embrace new practices may culminate to paradigm shift.

\section{$>$ Historical overview on Women's Rights Legal Framework \\ Women are among the vulnerable group whose fundamental rights have been adversely infringed since time immemorial due to historical, traditional and cultural bias; consequently perpetuate women disparities. Thus extra protection through comprehensive legal framework is required to enhance equality in enjoyment of their rights.}

\footnotetext{
${ }^{13}$ The Guidelines for Psychological Practice with Lesbian, Gay, and Bisexual Clients, adopted by the APA Council of Representatives, February 18-20, 2011. Also available on the APA website at http://www.apa.org/pi/lgbt/resources/guidelines.aspx.

${ }^{14}$ American Psychological Association, 2008, p. 28.

${ }^{15} \mathrm{https} / / /$ eige.europa.eu/thesaurus/terms/1162 accessed on 1st June, 2020.

${ }^{16}$ Bianchi, S. M., \&Milkie, M. A. (2010). Work and family research in the first decade of the 21 st century. Journal of Marriage and Family, 72 , 706-726
} 
Generally women's rights were first recognized globally under the preamble of the United Nation's Charter ${ }^{17}$ creates interpretations to equality between men and women

Moreover, the Universal Declaration of Human Rights(UDHR) ${ }^{18}$, under both its preamble and Article laddress women as having equal rights with men. Article 1 of the UDHR stipulates "All human being are born free and equal in dignity and rights”

Further, Article 3 of both International Covenant on Civil and Political rights ${ }^{19}$ (ICCPR) and International Covenant on Economic Social and Cultural Rights ${ }^{20}$ (ICESCR) enhance equality between men and women and prohibit all grounds of discrimination solely on bases of sex.

When the concept of equality between men and women at international level gained momentum the Convention on Elimination of all forms of Discrimination Against Women ${ }^{21}$ (CEDAW)as the most important and specific international instrument addressing women's right and setting acceptable measures and principles aimed at achieving equal rights was enacted. The Preamble of CEDAW acknowledges that women have been treated unequally and unfairly only because they are born women. It addresses both physical and psychological torture and discrimination of women.

The CEDAW recommend numerous measures for women's Rights to be fully realized. It prevents and prohibits all kinds of malpractices against women on areas such as political and public life, employment and job security, health services by providing measures to accelerate the realization of the three principles of equality, non-discrimination and participation of women in public. It emphasize that such preference should be temporal expected to ceases immediately after realizing the intended purpose and should not be considered discriminatory since it exist only for the purpose of correcting inequality in the society.

It should be noted that efforts to effective implementation of CEDAW has been hampered by too much reservations by state parties trying to preserve their religious and traditional practices incompatible to the purpose and objectives of CEDAW. It further calls on member states to guarantee positive and Corrective measures in eradication of all malpractices against women.

\footnotetext{
${ }^{17}$ United Nations Charter of 1945.

${ }^{18}$ Universal Declaration of Human Rights of 1948.

${ }^{19}$ International Covenant on Civil and Political rights, 1966 (ICCPR)

${ }^{20}$ International Covenant on Economic Social and Cultural Rights, 1966 (ICESCR)

21 The Convention on Elimination of all forms of Discrimination Against Women (CEDAW), 1979
}

The General Assembly adopted an Optional Protocol to CEDAW on $6^{\text {th }}$ of October, 1999 which came into force in the year 2000. The protocol provides for an avenue and procedure for all women to seek for redress against violation of their rights before the CEDAW Committee.

There are numerous international human rights instruments guaranteeing women's rights related matters which do not require too mush consideration. These include the United Nations Convention for Suppression of the Traffic in Persons and of the Exploitation of the Prostitution of Others ${ }^{22}$, The United Nations Convention on the Political Rights of Women ${ }^{23}$, The United Nations Convention on the Nationality of Married Women ${ }^{24}$, the Rome Statute of the International Criminal Court ${ }^{25}$ and numerous Conventions on International Labour Organization ${ }^{26}$ addressing specific aspects of women's rights to include but not limited to maternity rights, employment rights and equal opportunity for both women and men.

On African context is the Protocol on the African Charter of Human and Peoples Rights on the Rights of Women in Africa. ${ }^{27}$ The Protocol which came in force in 2005, aims at eradicating harmful practices such as female genital mutilation, reproductive rights and numerous economic and social rights intended to alleviate gender disparities. It incorporates some aspects found under CEDAW.

Tanzania in response to CEDAW requirement on states to ensure positive and collective measures alleviating malpractices adversely affecting women's rights, entrenches in its Constitution 28 prohibitions on discrimination on gender basis under Articles 13(5) and 24. This demands equal treatment on employment, ${ }^{29}$ property ownership $^{30}$ and inheritance. The Constitution ${ }^{31}$ further

\footnotetext{
${ }^{22}$ United Nations Convention for Suppression of the Traffic in Persons and of the Exploitation of the Prostitution of Others of 1949

${ }^{23}$ The United Nations Convention on the Political Rights of Women of 1952

${ }^{24}$ The United Nations Convention on the Nationality of Married Women of 1957

25 the Rome Statute of the International Criminal Court of 1998

${ }^{26}$ ILO 3 Convention of 1919, ILO 45 Convention of 1935 , ILO 89 Convention of 1948, ILO 100 Convention of 1951, ILO 102 Convention of 1952, ILO 103 Convention as revised by ILO 3 Convention of 1952, ILO 111 Conventions of 1958 and ILO 156 Convention of 1981.

27 the Protocol on the African Charter of Human and Peoples Rights on the Rights of Women in Africa of 2003

${ }^{28}$ The Constitution of the United Republic of Tanzania of 1977 as amended.

${ }^{29}$ Section 7(1), (4)-(h)(i) \&(j) of the Employment and Labour Relations Act, Cap 366[R.E 2019].

${ }^{30}$ Both sections 3(2) of the Land Act, Cap 113 and the Village Land Act, Cap 114 respectively.

${ }^{31}$ Article 66; Op citfn 12
} 
enumerates measures to alleviating inequality in political position by introducing $30 \%$ of special seats of women in the National Assembly intended to be shared by all political parties having representation from various won constituencies seats.

The Judiciary of Tanzania has exhibited great concern on ensuring equality in treatment and participation by pronouncing various customary laws detrimental to women's rights on land ownership and disposition ${ }^{32}$, unfair division of matrimonial assets ${ }^{33}$, denial in participation in administration of estate ${ }^{34}$ as discriminatory hence unconstitutional.

It is worth noting that though there are significant legal safeguards to alleviate gender disparities in Tanzania, there still exist policies, laws and practiced the adversely affect the realization of equal enjoyment of rights between men and women which require prompt amend to alleviate gender disparities.

\section{LEGAL FRAMEWORK ON GENDER DISPARITIES IN TANZANIA VIS-A VIS PRACTICE}

The status of women as inferior has been historically embraced and institutionalized, thus justifying unequal treatment which perpetuates disparities in the society. Despite having laws promoting women rights; still we have in place various laws that adversely affect women's rights in Tanzania. The following laws provide for substantive rights to women at the same time hamper the practical implementation. There are numerous policies and Laws that adversely affect women's Rights;

\section{$>$ The Constitution of the United Republic of Tanzania}

The Constitution as the mother law provide for general principles on right to equality and nondiscrimination under Articles 12(1) and 13(5) respectively. Equality requires equal treatment before the law without discrimination to guarantee that persons in equal circumstances be treated equally in law and practice. It should be noted that not every preferential treatment amount to discrimination. ${ }^{35}$ Discrimination under the ILO 111 Convention include; any distinction, exclusion or preference made on the basis of race, colour, sex... which has the effect of nullifying or impairing equality of opportunity or treatment in the employment or occupation. Thus there can only be discrimination if the following exists; ${ }^{36}$

\footnotetext{
${ }^{32}$ Bernado Ephraim vs. HolariaPastory and Another(PC) Civil Appeal No.252/1986.

${ }^{33}$ BiHawaMuhamed vs. Ally Sefu [1983] TLR 32.

${ }^{34}$ Elizabeth Stephen and Another vs. Attorney General [2006] TLR 404.

${ }^{35}$ Kamuli Raphael, (2012), Human Rights Law Global, Africa and Tanzanian Perspectives, Inland press, Mwanza, pg 155 .

${ }^{36}$ ibid
}

- Equal cases are treated in a different manner

- A difference in treatment does not have an objective and reasonable justification

- If there is no proportionality between the aim sought and the means employed.

The principle of equality calls for state to undertake affirmative or compensate for structural disadvantages created for ages against women. ${ }^{37}$ The purpose of having affirmative action is to elevate women to the same level as men. There can be effective only special preference does not raise women to the level higher than men since it will turn to be discrimination against men. Normally courts do employ numerous legal standards to evaluate legality or constitutionality of affirmative action employed by a state. The persistent status of inequality may justify affirmative action. The Maputo Protocol ${ }^{38}$ points out the existing discrimination against women in law and fact. In response to the deed to amend the inequality in treatment, the constitution vide its fourteenth Constitutional Amendment of 2005, increased Special seats for women in the National Assembly under Article $66^{39}$ to $30 \%$ share in accordance to the proportion of political parties percentage commensurate with won constituency seats.

Such affirmative action play a great role in Tanzania as it remedies the damages created by harmful practices. In Sukuma, Maasai and Hehe communities women are not allowed to talk before men. There cannot be called for a meeting. However these days among the maasai community incase a woman wishes to share something to the clan has to share her idea to a trusted man in her clan beforehand that he may present her ideas on her behalf. The existence of Baraza la Wanawake Tanzania 40 (BAWATA) advocates for preferential treatment to cub the gap against discrimination and marginalization of women. Most of customary laws in Tanzania places women in a disadvantages position when it comes to issues of inheritance, property ownership , reproductive health rights and custodian of children even though the constitution guarantee the same enjoyment of the said rights. ${ }^{41}$

\footnotetext{
${ }^{37}$ General Comment No.18 -Non Discrimination, Para 10 points out that, the principle of equality sometimes requires states parties to take affirmative action in order to diminish or eliminate conditions which cause or help to perpetuate discrimination ...

${ }^{38}$ African Union's Protocol to the African Charter on the Rights of Women in Africa (2003).

${ }^{39}$ The Constitution of the United Republic of Tanzania of 1977 as amended.

${ }^{40}$ Registered by the Registrar of Societies in May 1995 per Cap 337 R.E 2002.

${ }^{41}$ Articles 24, 12(1) and 13(5) of the Constitution of the United Republic of Tanzania of 1977 as amended.
} 
Traditionally women are overburdened with unnoticed and unrewarded labour which is simultaneously devalued. ${ }^{42}$ This include family child bearing and rearing, house work, taking care of spouses and aging parents and emotional labour, but have no control over their own reproductive health which include rights to privacy, equal treatment, health and family. Numerous societies do not allow women to plan for children spacing nor freedom from sexual exploitation and assault. Women have no say as men dictate over their reproductive rights. These causes stress and traumatize women since they are barred to express their feelings. The Protocol on the Rights of Women in Africa ${ }^{43}$ guarantees women's right to sexual and reproductive health. These include being informed about one's health status and that of her partner, child spacing and access to family planning, control of one's fertility protect self and be protected from sexually transmissible deceases such as HIV/AIDS.

It has been noted that irrespective of women being the major provider of long-term care who tend to outlive their spouses, are subjected to cultural practices that violate women's rights. ${ }^{44}$ These include early marriages, dowry price, son preference, early pregnancies, female genital mutilation and traditional birth practices which are justifiable acts in the eyes of those who practice them. ${ }^{45}$ Such harmful practices are embrace under religious books like the Bible in which female gender has been undermined and existence of women clergy has been strictly prohibited in the Catholic Church.

\section{$>$ Inheritance Laws}

Tanzania has three prevailing legal systems governing inheritance matters specifically on administration of deceased estate and succession. These include;Statute law, Islamic law and customary law though we haveHindu law ${ }^{46}$ which is prevalent among the Hindu community. These laws are discriminatory in nature on the basis of gender and they are inconsistent to the constitution and other statutory laws guaranteeing women' rights. There have been efforts for about three decades now propelling for reforms on inheritance laws. The law reform in 1987 started working on the draft law which was submitted to the ministry of justice by the ear 1995 but confined until in $2002^{47}$ but in vain.

${ }^{42}$ Ferree, M. M. (2010). Filling the glass: Gender perspectives on families.Journal of Marriage and Family, 72.

${ }^{43}$ Article 14 of the Protocol on the Rights of Women in Africa, 2003.

44 Family care giver Alliance: National Centre on Caregiving; also Available at https://www.caregiver.org Accessed on $16^{\text {th }}$ June, 2020 at 13:15 hrs.

${ }^{45}$ UNHCR, Fact Sheet No. 23 Harmful Traditional Practices Affecting the Health of Women and Children.

${ }^{46}$ Application of Hindu law as per JALA Cap.358 R.E 2002.

${ }^{47}$ Dancan Jenifer, Women's Land Rights guide for Tanzania, Nov. 2014

\section{- Customary Law}

Customary law has been defined in ChibayaMbuyape $v$ James Mlewa ${ }^{48}$ to mean laws originating from the customs of the tribes and remains as such until it becomes changed by general usage of the applied law. Customary rules of inheritance, succession to property of the deceased are based on patrilineal system. Customary rules are governed by the Second Schedule of the Local Customary Law (Declaration) (No.4) Order, 1963 which disproportionately favor male heirs. ${ }^{49}$

It is applicable to African members of the Community irrespective of their religious affiliation. ${ }^{50}$ There are three degrees in inheritance, whereas the first son from the first house is the heir in the first degree, second degree heirs include all other sons and third degree heirs are normally the daughters of the deceased.Where there are no male children then the first daughter from the first house inherit under the first degree of inheritance. Distribution of property among heirs in both the second and third degree is effected by age. The older one gets more than the young ones. Males get bigger share than females irrespective of their age. Among sukuma tribe male boys expect respect from their elder sisters and be greeted with great veneration while kneeling.

Moreover, in Scolastica Benedict $v$ Martin Benedict $^{51}$ it was shown that under Haya Customary law a widow has no share from the estate of her deceased husband if there are relatives from his husband's clan. She is supposed to reside and be maintained by her children. To the contrary, unless the deceased wife left no children of relative, the surviving husband cannot inherit from the estate of his deceased wife

Likewise rule $20^{52}$ women cannot inherit land rather for usufructuary use only. They cannot dispose it by sell while male have absolute inheritance to both movable and immovable properties. The High Court of Tanzaniahas dealt with such discriminatory provisions in various cases, in Bernado Ephrahim v. Holaria Pastory and Gervazi Kaizirege ${ }^{\mathbf{5 3}}$ Mwalusanya $\mathrm{J}$., declared this custom as being

${ }^{48}$ ChibayaMbuyape v James Mlewa (1967) HCD 434

${ }^{49}$ Amanda Ellis et al., (2007), Gender and Economic Growth in Tanzania:Creating Opportunities for Women. Pg 53.

${ }^{50}$ Volume 2 No.2 December 1988 Tanzania Law Reform Bulletin, p.56, 2. The Declaration set out in the First, Second and Third schedules ... the areas subject to the jurisdiction of Chunya, Dodoma, Kasulu, Kibondo, Kigoma, Kondoa, Manyoni, Maswa, Mbeya, Mpwapwa, Ngara, Njombe, Shinyanga, Singida, Songea, Ufipa, and Ukerewe District Councils and to be binding upon Africans, to whom the local customary law relates. It was extended to many more areas.

${ }^{51}$ Scolastica Benedict v Martin Benedict [1993] TLR 1

${ }^{52}$ Local Customary(Declaration) (No.4) Order, 1963

53 BernadoEphrahim v. HolariaPastory and GervaziKaizirege(PCC) Civil Appeal No.70 of 1989 (unreported) 
discriminatory and unconstitutional.The same position in which courts have challenged traditional inheritance practices in favour of women's rights includeKagabo s/o Mikaliha v Dandila d/o Biguna ${ }^{54}$ and Dausen F. Sawe v.Oforo Semi Swai ${ }^{55}$ respectively.Inheritance in Matrilineal society

Southern Tanzania comprises of Matrilineal communities ${ }^{56}$ in which distribution of property follows maternal relationship in which the society is generally disadvantaged since there customs are unwritten making it difficult to prove before the court as it is in Patrilineal societies. Unlike in Patrilineal communities where sons inherit land in Matrilineal communities nephews inherit immovable properties over women who my access land through a male relative. However, there are tremendous changes towards patrilineal practices among the Lugulu community.

Practically, all the prescribed rules are disproportionate to female as a widow has no share to her husband's estate so long as there are surviving children and relatives. Though it is expected that an elder son, has to take care of the widow to justify his lion's share of inheritance, to the contrary daughters take greater role in maintaining their aging parents irrespective of their economic status. In addition to the fact the most appointed administrators under customary rules are male, they appear to pose as beneficiaries and misappropriate the estate for themselves. In Elizabeth Stephen and Another v. Attorney General $^{57}$ customary practices that deny women right to inheritance and participation in administration of estate were declared discriminatory thus unconstitutional.

\section{- Islamic Law}

Inheritance under Islamic law evolves among deceased's successors in a system known as mirath; where the property evolves only those who are related by consanguinity or marriage. ${ }^{58}$ Under Islamic law the widow inherits $1 / 8$ of the deceased husbands' estate if he was survived by children and $1 / 4$ there are no surviving children. The remaining share goes to other heirs in which female heirs normally receive half of male heirs. Distribution is governed by Qur'an thus justifying discrimination from religious perspective.

\footnotetext{
${ }^{54}$ Kagabo s/o Mikaliha v Dandila d/o Biguna (1967) HCD 428

${ }^{55}$ Dausen F. Sawe v Oforo Semi Swai (1967) HCD 429

${ }^{56}$ It includes the tribes of Yao, Makonde, Luguru, Makua, Wamwera and more others. The communities are directly attached to an elder brother of the sister who acts as leader of the family.

${ }^{57}$ Elizabeth Stephen and Another v. Attorney General [2006] T.L.R 404.

${ }^{58}$ Abdul Rahman I. Doi, (1984), Shariah, The Islamic Law, Ta Ha Publishers London,UK,p.272.
}

\section{- Statutory Law}

The Indian Succession Act ${ }^{59}$ is the statutory law applicable to Christians. ${ }^{60}$ it is still applicable in the country since it recognize that widows have share of inheritance to their deceased husband though subject to European origin. In Re: Innocent Mbilinyi ${ }^{\mathbf{6}}$ upon the untimely demise of Innocent Mbilinyi who died intestate, his relatives wanted to disinherit the widow per Ngoni customary law. The court resulted to Mode of life test applicable to Christian of African origin to determine whether the deceased had in his lifetime abandoned his customary way of life in favor of what may be called Christian and non-traditional way and held that Indian Succession Act was applicable and consequently the widow had share to her deceased husband's estate since the deceased had in his lifetime abandoned customary way of life in favour of Christianity.

\section{Employment Law}

Employment laws in Tanzania to a great extent adhere to the principle of equality and nondiscrimination.Sections 7(1), (4)-(h) (i) and (j) of the Employment and Labour Relations $\mathrm{Act}^{62}$ are of the effect that no direct or indirect discrimination in practices or in employment policy based on sex, gender or pregnancy. It has been noted that for a long time unmarried pregnant working woman has been accorded with 84days paid maternity leave under the Employment Ordinance (Amendment). ${ }^{63}$ This paid leave was accorded on equal footing to both married and unmarried pregnant working women. This position has thus being maintained under Sections 33-(6) (a) and (b) of the Employment and Labour Relations Act $^{64}$ in which working pregnant women are entitled to 84 days paid leave or 100 days paid leave if a woman happens at the same time to give birth to more than one child. ${ }^{65}$ Likewise the law requires the government to ensure reasonable measures to promote equality and eliminate discrimination based on gender to all persons with disabilities. ${ }^{66}$

Equality in employment is a constitutional right in which an employee requires fair remuneration. ${ }^{67}$ The said right to work should be accessible to women on equal footing with men to every office and functions under the

\footnotetext{
${ }^{59}$ The Indian Succession Act 1865.

${ }^{60}$ It does not apply to the Hindu, Muslim, Buddhists, Sikhs or Jains.

${ }^{61}$ Re: Innocent Mbilinyi [1969] H.C.D n.283.

${ }^{62}$ The Employment and Labour Relations Act, Cap 466 [R.E 2019].

${ }^{63}$ The Employment Ordinance (Amendment) of 1975.

${ }^{64}$ The Employment and Labour Relations Act, Cap 466.

${ }^{65}$ The same position has been spelt out under Article 10 of the International Covenant on Economic Social and Cultural Rights (ICESCR) of 1966.

${ }^{66}$ Per Section $6(6)$ of the Persons with Disabilities Act, 2010.

${ }^{67}$ Per Articla 22 and 23 of the Constitution of the United Republic of Tanzania of 1977.
} 
state. ${ }^{68}$ An employee is entitled to other general rights including right to form and join any trade union, right to strike and lock out to employers in terms of dispute of interest. ${ }^{69}$ The right to fair enumeration under the constitution guarantees protection of vulnerable workers who cannot assert their rights through negotiation because of the market economy contemporary nature. ${ }^{70}$ Consequently, elevates women who have been structurally disadvantaged in every aspect of life.

\section{$>$ Land Laws}

Generally the legal framework on land upholds women's equal rights to property. Section 3of the Land Act ${ }^{71}$ stipulates for principles that safeguards women's right to acquire, hold use and deal with land on equal footing with men subject to the same restriction. Since major legal reform on land laws in 1999, the law permits private property rights and integrates customary tenure. This includes equitable distribution of land, women's participation in decision making concerning property rights and equal access to land. Section 12 of the Village Land $\mathrm{Act}^{72}$ governs village land that can be allocated by village council subject to approval by the village Assembly. The village council is required to treat all persons applying for customary right of occupancy without discrimination irrespective of gender. Further Section 30(4)(b) of the same Act, prohibits villagers to assign if it would interfere with the rights of any woman. Women are accorded with opportunity to participate fully in decision making in order to safeguard their interest. To that end, the Minister of Land, Housing and Human Settlements Development should strike a fair balance in appointing members to the Land Advisory Council.The Constitution guarantees equal right to property ownership without discrimination. ${ }^{73}$ Tanzania has signified it intention to uphold equality on property right by signing and ratifying numerous international instruments without any reservation. ${ }^{74}$

Although Tanzania has undergone tremendous reform in upholding women's land rights both at International and domestic level, practice shows rare implementation. There still co-exist conflicting and discriminatory laws on matters of inheritance and marriages that harm women. Even though the law requires women to possess at least $1 / 3$ of the members to the District Council ${ }^{75}$ who can help to balance

${ }^{68}$ Article 22(2) of the same Constitution and article 6(1) of the ICESCR, 1966.

${ }^{69}$ Section 9(1)(a) and (b) and Section 75 of the Employment and Labour Relations Act, Cap 366respectively.

${ }^{70}$ Kamuli (Supra)p. 138.

${ }^{71}$ Land Act, Cap 113 and the National Land Policy 1995.

${ }^{72}$ Village Land Act, Cap 114 [RE 2019].

${ }^{73}$ Articles 24 and 13 of the Constitution of the United Republic of Tanzania of 1977.

${ }^{74}$ These include the ICCPR, ICESCR, CEDAW and the Maputo Protocol as cited above.

${ }^{75}$ The Local Government(District Authorities) Act of 1982 and Local Government (Urban Authorities) Act of 1982 as amended in 2002 for affirmative action. Also see the sections 53(2) and 60(2)(9) of the Village land Act, Cap land allocation, practice shows male dominance and frequency allocation of land to men household. ${ }^{76}$ Additionally the Local Customary Law (Declaration ) Order GN.279 and GN. 436 of 1963 provides for customary law related to land, inheritance and marriage applicable to patrilineal societies. These laws contradict statutory laws .section 181 of the Land Act, provide for the position incase there exist any law inconsistency to the Land Act on land matters, then the Land Act must prevail. To that end courts in SeifMarare v. MwadawaSalum ${ }^{77}$ stated that,in case of conflicting provisions between customary law and statutory law, then statute law should apply.

\section{$>$ Marriage Law}

The Law of Marriage Act $^{78}$ stipulates for equality between spouses on Civil, Islamic and Customary marriages. That for marriage to be valid there must be free consent of all spouses. It has been noted that both Islamic and Customary law conflict the Law of Marriage, inheritance, bride price and on consequences of divorce.Section 59 of the law of marriage Act prohibit disposition of matrimonial home without spousal consent. This is in conformity to section 159(4) of the Land $\mathrm{Act}^{79}$ in which spouses create joint occupancy where there is no separate share even when one of the spouse dies, interest shall vest in the surviving spouse or occupier. ${ }^{80}$ The Village Land $\mathrm{Act}^{81}$ prohibits any attempt to surrender customary right of occupancy which would deprive or harm the rights of a woman in occupancy by making such act void in not consented to in writing. Safeguard is evident that the Land Act prohibits both lease and mortgage transactions that discriminate women. ${ }^{82}$

However, Section 13 of the law of marriage, ${ }^{83}$ Permits courts to allow marriage between two persons of different sex, where the male person must have attained the age of eighteen (18) and 14 or 15 for a female. ${ }^{84}$ The practice brings disharmony in laws concerning marriage; thus, increase the magnitude on gender disparities. ${ }^{85}$ Section $10^{86}$

114 and section 11 of the Court(Land Dispute Courts) Act, Cap 216.

76 Dancan Jenifer, Women's Land Rights guide for Tanzania, Nov. 2014.

${ }^{77}$ SeifMarare v.MwadawaSalum [1985] TLR 253.

${ }^{78}$ The Law of Marriage Act, Cap 29 [RE 2019]

79 The Land Act, Cap 113 [RE 2019].

${ }^{80}$ Section 159(4)(a-c) of the Law of Marriage Act, Cap 29.

${ }^{81}$ Section 35(2) and Section (7)(c)(i) of the Village Land Act, Cap 114 [RE 2019].

${ }^{82}$ Sections 93(2), 141 and 142 of theLand Act, Cap 113 [RE 2019].

${ }^{83}$ Law of Marriage Act, Cap 29 [R.E 2019].

${ }^{84}$ Sr. Ester John Kilatu.(Volume. 4 Issue. 3, March - 2019), "Justice against Child Abuse", International Journal of Innovative Science and Research Technology (IJISRT), www.ijisrt.com. ISSN - 2456-2165,Pg 570.

${ }^{85}$ The Penal Code permits a person of African origin or Asiactic descent to marry a girl under the age of 12 if 
makes a woman liable for an offence punishable to either fine or imprisonment or both against any woman who neglect to maintain a child. The provision ought to have premised itself on gender neutrality rather than incriminating women alone on matters of child maintenance instead economic factor should have been considered and applied to all both spouses.

Further the act portrays women as inferior to men as it permits men to marry more than four wives under Islamic marriage though the woman may object on ground that marriage would result to hardship for herself or her children. ${ }^{87}$ Section $125(2)$ (c) of the Law of Marriage $\mathrm{Act}^{88}$ Permits court when deciding issues on custody of children to consider the custom of the community. It is evident that customary law of inheritance is patriarchal in nature and at odds with shielding women's rights. Though under the Law of Marriage Act women are permitted to acquire, hold, dispose and the right to distribute properties jointly acquired upon divorce, ${ }^{89}$ practice shows that the stated entitlement is barred under inheritance lawssince the choice of law governing inheritance is complex. Thus, prohibit women from inheriting immovable propertyand enjoying the same right as men. ${ }^{90}$

\section{$>$ Participation Rights}

The right to participate manifests on the possibility of a person's involvement in decision making on matters affecting her or his interests. It requires affordable opportunity to excise one's freedom of association, assembly and the rights to vote and be voted which form the basis in which citizens are involved in decision making through representative democracy for public manifestation. ${ }^{91}$ Participation in public affairs involving the poor has been viewed as the core of human rights based approach leading to development and poverty alleviation. ${ }^{92}$

Generally the right to participate has been recognized at international level, regional and national level. In specific, Article 7 of the Convention on Elimination of all forms of Discrimination against Women ${ }^{93}$ provides for women's right to participate on equal footing with men in all elections, political, public affairs and public referenda. ${ }^{94}$

consummation is not intended before 12 years of age. The practice is evident among the Maasai societies.

${ }^{86}$ Law of Marriage Act, Cap 29 [R.E 2019]

${ }^{87}$ Section 20 of the Law of Marriage Act, Cap 29 [R.E 2019]

88 Ibid.

${ }^{89}$ Sections $56-58$ of the Law of Marriage Act, Cap 29 [RE 2019].

${ }^{90}$ See rule 20 of the Local Customary (Declaration) (No.4) Order, 1963.

${ }^{91}$ Kamuli (Supra) pg. 141.

${ }^{92}$ ibid

93 The Convention on Elimination of all forms of Discrimination Against Women, 1979.

${ }^{94}$ Also see Article 21(1) of the UDHR, Article 13 and 20 of the ACHPR and Article 21 of the Constitution of the United Republic of Tanzania respectively.
Tanzania entitles every citizen above the age of 18 to vote in any election ${ }^{95}$ and provision of special seats for women. ${ }^{96}$

It is contended that gender ideology favour men by prioritizing men's paid work over women; that men are likely to spend many hours at work while women may miss work to care for their sick children and during maternity. ${ }^{97}$ Moreover, non-heterosexual women contends to face severe social stigma and discrimination over heterosexism women as they are seen to conduct themselves contrary to acceptable social standard portraying human dignity while heterosexual women desire for legal framework to reclaim them.

Practice reveals a little progress in women participation in electoral process. The 2015 Political campaigns witnessed the participation of two women namely Ms. Anna Ngwhira (ACT-Wazalendo) and Ms. SamiaSuluhu Hassan (CCM) who contested for presidential race and presidential running mate respectively. Despite having a greater number of women who registered and participate in 2015 general election... ${ }^{98}$ there was very low turn-out on women's campaigns and a very low percentage of women's votes on top posts compared to men's. This implies that there is distrust in women's capacity to lead the country on top position. ${ }^{99}$ There was further revealed lack of readiness and confidence on women's voters from their fellow women. According to Legal and Human Rights Centers observer to both the 2010 and 2015 general election, women voters expressed inadequate support on their fellow women some were pretending that 'women are able at the same time preventing and failing them from climbing up to power. ${ }^{100}$

Distrusting women is attributed to patriarchal system which diminishes women status in the society. The practice has been prevalent not only in Tanzania but also in most

\footnotetext{
${ }^{95}$ Article $5(1)$ of the Constitution of the United Republic of Tanzania.

${ }^{96}$ Article 78 of the same Constitution.

${ }^{97}$ G.W. Peterson and K.R. Bush (eds.),(2013) Handbook of Marriage and the Family, DOI 10.1007/978-1-4614-39875_7, () Springer Science+Business Media New York, pg.147; Cha, Y. (2010), Reinforcing separate spheres: The effect of spousal overwork on men's and women's employment in dual-earner households. American Sociological Review, 75 .

${ }^{98}$ Report on the Observation of the 2015 General Election in Tanzania , Legal and Human Rights Center(LHRC) \& Tanzania Civil Society Consortium for Election Observation (TACCEO), 2016.

${ }^{99}$ Ms. Anna Mghwira of ACT - Wazalendo got less than one percent of all votes.

${ }^{100}$ Comment from a bar attendant at MbeziGogoni area in Dar es salaam as translated in English. "women are so arrogant, looh! If given leadership position, they will not listen to you, especially when you are a woman..."see Report on the observation of the 2015 General Election in Tanzania LHRC \& TACCEO, 2016, pg. 110.
} 
African countries despite the presence of strong legal framework safeguarding women's rights and feminist movement. Kemi Ogunsanya ${ }^{101}$ observed that women's participation in politics is require preparedness to fight against many biases battles based on stereotyping tendencies, sexism, corruption and hostility. Stereotyping is blatantly manifested publicly even in the General Assembly sessions. The role of media is expected to restructure the society's attitudes towards, the capacity of women in leadership. Thus calls for women empowerment on taking leadership role both materially and psychologically and the societies attitude to change from embracing harmful cultural practices detrimental to women's right to participate in the society.

However, women who contest for posts below presidency have stood triumphantly in advancing arguments, analyzing issues and defending their points, thus represent 50 percent chance of winning per the table below;

\begin{tabular}{|c|c|c|c|}
\hline Party & $\begin{array}{c}\text { Number of } \\
\text { Contestants } \\
\text { in 2015 }\end{array}$ & $\begin{array}{c}\text { Number } \\
\text { of } \\
\text { Women } \\
\text { who won } \\
\text { in 2015 }\end{array}$ & $\begin{array}{c}\text { Parliamentary } \\
\text { Special Seats } \\
\text { in 2015 }\end{array}$ \\
\hline CCM & 19 & $15(79 \%)$ & 64 \\
\hline CHADEMA & 15 & $6(40 \%)$ & 36 \\
\hline CUF & 6 & $1(17 \%)$ & 10 \\
\hline Total & $\mathbf{4 0}$ & $\mathbf{2 2 ( 5 5 \% )}$ & $\mathbf{1 1 0}$ \\
\hline
\end{tabular}

Table 1

Source: Report on the Observation of the 2015 General

Election in Tanzania, Legal and Human Rights Centre (LHRC) \& Tanzania Civil Society Consortium for Election Observation (TACCEO), 2016, pg. 323.

The table further shows an increase in number of special seats for women which raised considerable with the increase of more women who won in various constituencies. Even though realising SADC threshold of $50 \%$ is a far reach dream. Even in other public position like leadership position at University level, women are still subjected to biasness despite the education status of participants. During 2020 election preparations, some women organized for conference as a forum to share different experiences and strategies on how to compete with men during election campaign. Though for over years the countries are recorded to have achieved notable progress on gender equality in political representation, employment in paid jobs other than agriculture and in primary education. ${ }^{102}$ Irrespective of continuous progress,

${ }^{101}$ Ogunsanya, Kemi (Undated), Women and Elections in African Politics.Also available at https://media.africaportal.org/documents/op_2007_3women _transforming.pdf Accessed on 24th June, 2020 at 16:26 hrs.

${ }^{102}$ UN Report on Millennium Development Goals (MDGAS) 2015. the report ${ }^{103}$ reveals persistence discrimination against women in Education at higher learning institutions, economic assets poor involvement in public matters and traditional stereotyping which has disempowered women from taking leadership position only because they are born women. This does not only affect women's participation but it goes further to affect one's mental health leading to depression and anxiety.

Moreover, participation right is very broad as it is directly linked with right to freedom of conscience and religion. It is argued that thoughts and beliefs are relevant when expressed, thus guarantee for the right to freedom of expression, assembly, association and the right to privacy are inevitable in upholding religious beliefs. Freedom of conscience and religion in Tanzania is qualified thus not absolute right. It's application is subject to law. ${ }^{104}$ Article 19(1) of the Constitution ${ }^{105}$ that "every person has right to the freedom of conscience, faith and choice in matters of religion..."

Participation rights on religious matters exclude women's involvement in leadership especially in the Catholic Church. Despite constituting half of Catholicism's 1.2 billion adherents, women have little power in decision making since they are barred from voting at Vatican Synods, and from being ordained priests. Pope Francis in his new years' sermon declared that women should be fully included in decision making process in the church; to that end he has recently named a woman in the secretariat of state to a managerial position. This is the Vatican's most important office ${ }^{106}$ and urged religious to render their mission as service and not servitude, thus they cannot be servants of a cleric. ${ }^{107}$ In Tanzania Wanawake Wakatoliki Tanzania (WAWATA) means Catholic Women have proved to be the most effective institution which promotes the church's mission by supporting the clergy, seminaries and development activities. For example WAWATA in the Archdiocese of Arusha offers among others hosts, Easter candle and wine to all parishes and seminaries. Failure to empower women in the church, narrows the church's vision since women possess the sixth sense that is intuition which men lacks. Thus, affect economic development of the society.

\footnotetext{
${ }^{103}$ Ibid.

${ }^{104}$ See Article 8 of the African Charter on Human and people's rights, 1981.

${ }^{105}$ The Constitution of the United Republic of Tanzania of 1977 as amended.

106 https://www.nbcnews.com/think/opinion/pope-francisput-woman-top-vatican-role-it-shows-how-ncna1119661

Accessed on 24th June, 2020 at 15:50 hrs.

$107 \quad$ https://www.vaticannews.va/en/pope/news/201905/pope-francis-superiors-general-meeting.htmlAccessed on 24th June, 2020 at 16:45 hrs.
} 


\section{CONCLUSION AND RECOMMENDATION}

\section{A. Conclusion}

Generally women are quintessential caregiver and have a burden of an invisible labour which is coupled by harmful traditional practices that create a paradigm which requires concerted efforts to abandon and embrace new practices.

That, land laws provide for equal rights in land ownership between men and women but such right has been qualified under inheritance and marriage laws which discriminate women and diversely affect their land rights.

Prioritizing men's paid work over that of women, places committed women at a disadvantage leading to stress, depression and anxiety if such dissatisfaction on involvement is prolonged.

Affirmative action is necessary to remedy the damages created by harmful practicessince the purpose of having affirmative action is to elevate women to the same level as men; since women are overburdened with unnoticed and unrewarded labour which is simultaneously devalued.

Most of customary laws in Tanzania places women in a disadvantages position when it comes to issues of inheritance, property ownership, reproductive health rights and custodian of children even though the constitution guarantee the same enjoyment of the said rights

The right to fair enumeration under the constitution guarantees protection of vulnerable workers, thus, elevates women who have been structurally disadvantaged in every aspect of life.

It is contended that gender ideology favour men by prioritizing men's paid work over women; that men are likely to spend many hours at work while women may miss work to care for their sick children and during maternity.

Moreover, non-heterosexual women face social stigma and discrimination over heterosexism women as they are seen to conduct themselves contrary to acceptable social standard which are regarded to portray societal dignity.

Women participation in politics is hampered by distrust. Distrusting women is attributed to patriarchal system which diminishes women status in the society. Consequently the society including women has been reluctant on trusting women's voters.

\section{B. Recommendations}

Accordingly, the society shouldembrace 'will' writing practices and willingness of the court is anticipated to honor and enforce the law may mitigate the problem since reform on inheritance law has been proved ineffective despite concerted efforts from lawyers.
Moreover, there is a need to involve women in both private sectors and public life as a means to emancipate them from gender iniquities and accelerate economic development.Organizing conferences involving different participants at both national and international level addressing all forms of discrimination against women which hinder the efforts in achieving gender parity may meet the aim.

There should be geographical and cultural consideration in prioritizing gender issues at global level since what may be priority in one continent does not necessarily be a problem in another country.

Additionally, those who are discriminated from work based solely on gender may take such situation positively as an opportunity to create autonomy and explore more avenues for self-employment in order to realize job satisfaction as a means to achieve gender parity.

There should be commitment from public policy maker on the need to mitigate gender disparities and push for framework to freely reclaim non-heterosexual.

\section{REFERENCES}

\section{$>B O O K S$}

[1]. Abdul Rahman I. Doi, (1984), Shariah, The Islamic Law, Ta Ha Publishers London, United Kingdom.

[2]. Black J. et al, (2009), A practical Approach to Family Law, Oxford University Press.

[3]. G.W. Peterson and K.R. Bush (eds.), (2013); Handbook of Marriage and the Family, DOI 10.1007/978-1-4614-3987-5_7, C C Springer Science+Business Media New York.

[4]. Herrings , J , (2008), Family Law, Longman Law Series.

[5]. Jackson M. R., (1998), Destined for Equality, New York. Cambridge University Press.

[6]. Kamuli, Raphael, (2012), Human Rights Law, Global, Africa and Tanzanian Perspectives, Mwanza, Inland Press.

[7]. M.K. Rwebangira\&Mukoyogo, The law of Inheritance in Tanzania, A status Report, WLEA, Nairobi, 1995

[8]. Mashamba, J.C, Introduction to Family Law In Tanzania, Institution of Public Policy and Law \& NOLA, 2010

[9]. Njega, F.C, (1116),The Law of Succession-East Africa, University College Dar es salaam.

[10]. Oakley, A. (1972) Sex, Gender, and Society. London: Temple Smith.

[11]. Ralph C. Brashier,Inheritance Law and the Evolving Family, Temple University Press, Philadelphia, 2004

[12]. W.M. Musyoka, Law of Succession, Kijabe Printing Press, Nairobi, 2008 
ARTICLES FROM JOURNALS /PAPER/REPORTS

[1]. Bianchi, S. M., \&Milkie, M. A, (2010), Work and family research in the fi $r$ st decade of the $21 \mathrm{st}$ century. Journal of Marriage and Family, 72, 706726.

[2]. Cha, Y, (2010), Reinforcing separate spheres: The effect of spousal overwork on men's and women's employment in dual-earner households. American Sociological Review, 75 , 303-329.

[3]. Dancan Jenifer, Report on Women's Land Rights guide for Tanzania, Nov. 2014.

[4]. FAO. (1997)Gender: the key to sustainability and food security. SD Dimensions, May 1997 (http: //www. fao.org/sd).

[5]. Ferree, M. M. (2010); Filling the glass: Gender perspectives on families; Journal of Marriage and Family, 72 , 420-439.

[6]. Giuliano P, (2017), Gender: An Historical Perspective, Bonn, IZA - Institute of Labor

Economics.

[7]. Moser, C. (1989), Gender planning in the Third World: Meeting practical and strategic gender needs. World Development, Vol. 17 (11): 1799-1825.

[8]. Reeves H. and Baden S. (2000), Gender and Development: Concepts and Definitions. London: Institute of Development Studies University of Sussex.

[9]. Report on the Observation of the 2015 General Election in Tanzania, Legal and Human Rights Centre (LHRC) \& Tanzania Civil Society Consortium for Election Observation (TACCEO), 2016.

[10]. SOFA Team (2011), Gender differences in assetsESA Working Paper No. 11-12

[11]. Sr. Ester John Kilatu, (Volume. 4 Issue. 3, March 2019), "Justice against Child Abuse", International Journal of Innovative Science and Research Technology (IJISRT), www.ijisrt.com.ISSN - 24562165.

[12]. The Guidelines for Psychological Practice (2001), Definition of Terms: Sex, Gender, Gender Identity, Sexual Orientation. American Psychological Association,http://www.apa.org/pi/lgbt/resources/guid elines.aspx.

[13]. The Guidelines for Psychological Practice with Lesbian, Gay, and Bisexual Clients, adopted by the APA Council of Representatives, February 18-20, 2011.

[14]. UN Report on Millennium Development Goals (MDGAS) 2015

\section{STATUTES}

[1]. African Union's Protocol to the African Charter on the Rights of Women in Africa (2003).

[2]. Law of Marriage Act, No.5 of 1971, Cap 29 [R.E 2019].

[3]. The Constitution of the United Republic of Tanzania of 1977 as amended.

[4]. The Employment and Labour Relations Act, Cap 366 [R.E 2019].

[5]. The Evidence Act, Cap 6 [R.E 2019]

[6]. The Indian Succession Act 1865.
[7]. The Labour Institutions Act, Cap 300 [R.E 2019].

[8]. The Land Dispute Courts Act, Cap 216 [R.E 2019]

[9]. The Land Act, Cap 113[R.E 2019].

[10]. The Magistrates Court Act, Cap 11 [R.E 2019].

[11]. The National Land Policy 1995.

[12]. The Penal Code, Cap 16 [R.E 2019].

[13]. The Persons with Disabilities Act, 2010.

[14]. The Village Land Act, Cap 114 [RE 2019].

\section{RULES}

[1]. Local Customary (Declaration) (No.4) Order, 1963.

\section{CASE LAW}

[1]. BernadoEphrahim v. HolariaPastory and GervaziKaizirege(PCC) Civil Appeal No.70 of 1989 (unreported).

[2]. BiHawaMuhamed vs. Ally Sefu [1983] TLR 32.

[3]. ChibayaMbuyape v James Mlewa (1967) HCD 434

[4]. Dausen F. Sawe v Oforo Semi Swai (1967) HCD 429.

[5]. Elizabeth Stephen and Another vs. Attorney General [2006] TLR 404.

[6]. Kagabo s/o Mikaliha v Dandila d/o Biguna (1967) HCD 428.

[7]. Re: Innocent Mbilinyi [1969] H.C.D n.283.

[8]. Scolastica Benedict v Martin Benedict [1993] TLR 1.

[9]. SeifMarare v. MwadawaSalum [1985] TLR 253.

\section{CONVENTION}

[1]. ILO 100 Convention of 1951.

[2]. ILO 102 Convention of 1952.

[3]. ILO 103 Convention as revised by ILO 3 Convention of 1952.

[4]. ILO 111 Conventions of 1958.

[5]. ILO 156 Convention of 1981.

[6]. ILO 3 Convention of 1919.

[7]. ILO 45 Convention of 1935.

[8]. ILO 89 Convention of 1948.

[9]. International Covenant on Civil and Political rights, 1966.

[10]. International Covenant on Economic Social and Cultural Rights, 1966.

[11]. The African Charter on Human and people's rights, 1981.

[12]. The Convention on Elimination of all forms of Discrimination Against Women (CEDAW), 1979.

[13]. The Protocol on the African Charter of Human and Peoples Rights on the Rights of Women in Africa of 2003

[14]. The Rome Statute of the International Criminal Court of 1998.

[15]. The United Nations Convention on the Nationality of Married Women of 1957

[16]. The United Nations Convention on the Political Rights of Women of 1952.

[17]. United Nations Charter of 1945.

[18]. United Nations Convention for Suppression of the Traffic in Persons and of the Exploitation of the Prostitution of Others of 1949.

[19]. Universal Declaration of Human Rights of 1948. 


\section{INTERNET}

[1]. http://www.apa.org/pi/lgbt/resources/guidelines.aspx Accessed on 09th July, 2020.

[2]. https://eige.europa.eu/thesaurus/terms/1162 accessed on 1st June, 2020.

[3]. https://media.africaportal.org/documents/op_2007_3w omen_transforming.pdf Accessed on 24th June, 2020.

[4]. https://www.britannica.com/topic/feminism Accessed on 09th July, 2020.

[5]. https://www.nbcnews.com/think/opinion/popefrancis-put-woman-top-vatican-role-it-shows-howncna1119661 Accessed on 24th June, 2020.

[6]. https://www.vaticannews.va/en/pope/news/201905/pope-francis-superiors-general-meeting.html Accessed on 24th June, 2020. 